\title{
Catecholase Activity Associated with Copper-S100B ${ }^{\dagger}$
}

\author{
SueAnn Z. Senior ${ }^{\ddagger}$ Laura L. Mans, ${ }^{\ddagger}$ Heather D. VanGuilder, ${ }^{\ddagger}$ Kimberly A. Kelly, ${ }^{\ddagger}$ Michael P. Hendrich,${ }^{\S}$ and \\ Timothy E. Elgren*,* \\ Department of Chemistry, Hamilton College, Clinton, New York 13323, and Department of Chemistry, \\ Carnegie Mellon University, Pittsburgh, Pennsylvania 15213
}

Received September 9, 2002; Revised Manuscript Received February 19, 2003

\begin{abstract}
This study addresses the spectroscopic properties and reactivity associated with the copperloaded form of S100B isolated from bovine brain. Copper(II)-S100B displays EPR features typical of a type II copper center and is shown here to exhibit catecholase activity, the two-electron oxidation of catechols. The steady-state kinetics associated with the oxidation of several catecholamines has been probed in order to further characterize this activity. The evidence provided indicates that the catecholase chemistry is copper initiated. Superoxide dismutase has no effect on the rates of catecholamine oxidation catalyzed by $\mathrm{Cu}-\mathrm{S} 100 \mathrm{~B}$, establishing that superoxide is not produced during this reaction, ruling out an autoxidative mechanism. Addition of catalase to the $\mathrm{Cu}-\mathrm{S} 100 \mathrm{~B}$ reaction with catechols reduces the amount of oxygen consumed by $50 \%$, demonstrating that peroxide is released during this reaction. The release of peroxide is mechanistically distinct from the type III dinuclear copper proteins, catechol oxidase and tyrosinase.
\end{abstract}

S100B is a small, highly acidic protein and a member of the S100 family of related proteins (1). It is synthesized primarily in glial cells of the vertebrate nervous system and Schwann cells of the peripheral nervous system (2). S100B is a homodimer $(\beta \beta)$ with a monomer molecular mass of $10565 \mathrm{Da}(3)$. The protein has been detected in a number of other tissues outside the nervous system including melanocytic tumor cells, where its levels are 100 times that of normal skin cells (4). It is proposed to alter microtubule assembly (5) and dissociation (6), cause activation of fructose-1,6-bisphosphate aldolase (7), inhibition of protein kinase C-mediated phosphorylation (8), and activate guanylate cyclase (9).

S100B, like most other dimeric S100 proteins studied, binds four $\mathrm{Ca}$ (II) ions per protein dimer with binding constants around $3 \times 10^{3} \mathrm{M}^{-1}(10,11)$. Solution (12) and crystal $(13,14)$ structures of S100B isolated from bovine brain have been recently reported. The structures support earlier characterization of the protein as having homologies with the EF-hand calcium binding proteins, such as calmodulin. These studies confirm Asp and Glu residues as the primary endogenous carboxylate ligands that make up the oxygen-rich coordination sphere of the bound $\mathrm{Ca}(\mathrm{II})$. As with other calcium binding proteins, the extent of calcium loading depends on the ionic strength and $\mathrm{pH}$ environment (15). Each of the $\beta$ monomers that comprise the $\mathrm{S} 100 \mathrm{~B}$ dimer is capable of binding 2 equiv of $\mathrm{Ca}(\mathrm{II})$ at $\mathrm{pH} 8.3$ or greater. One $\mathrm{Ca}$ (II) is bound between $\mathrm{pH} 7.0$ and $\mathrm{pH} 7.5$. No $\mathrm{Ca}$ (II) is bound at $\mathrm{pH}$ values less than 6.0 .

\footnotetext{
Acknowledgment is made to the donors of the Petroleum Research Fund, administered by the American Chemical Society (T.E.E.), the National Institutes of Health (1 R15 NS35340-01A1) (T.E.E.), and the Research Corporation (T.E.E.) for support of this research.

* To whom correspondence should be addressed. Phone: (315) 8594695. Fax: (315) 859-4677. E-mail: telgren@hamilton.edu.

Hamilton College.

$\S$ Carnegie Mellon University.
}

Zinc and copper have also been shown to bind to S100B. While $\mathrm{Zn}$ (II) binds to most $\mathrm{S} 100$ proteins with stoichiometries ranging from 2 to $8 \mathrm{Zn}$ (II) per dimer, only S100B has been reported to bind copper. S100B displays a strong affinity for $\mathrm{Zn}(\mathrm{II})\left(K_{\mathrm{Zn}(\mathrm{II})}=1 \times 10^{6} \mathrm{M}^{-1}\right)(11)$. The $\mathrm{Zn}(\mathrm{II})$ binding sites, which likely incorporate some or all of the five His residues, are clearly distinct from the $\mathrm{Ca}$ (II) binding sites. $\mathrm{S} 100 \mathrm{~B}$ can bind 2 equiv of copper per peptide $\left(K_{\mathrm{Cu}(\mathrm{II})}\right.$ $\left.=2.2 \times 10^{6} \mathrm{M}^{-1}\right)$, most of which can be displaced with 1 $\mathrm{mM} \mathrm{Zn}(\mathrm{II})$, suggesting that they occupy the same binding site (16). Little is known about the structure and reactivity associated with the copper-loaded form of S100B.

Copper is known to play a number of vital roles in neurochemistry, primarily that of a redox-active cofactor in a variety of metalloprotein active sites. Copper-catalyzed or -initiated oxidative damage may play a role in the progression of neurological diseases, such as Parkinson's (17), Alzheimer's (18), amyotrophic lateral sclerosis (ALS) (19), and prion-related (20) diseases. Copper concentrations in cerebrospinal fluid correlate with the severity and rate of progression of the degradation of dopaminergic neurons in Parkinson's disease. The recent report that the upper limit of "free" or unchelated copper within eukaryotic cells is less than one copper atom per cell (21) raises important questions about the bioavailability of redox-active copper. Pall et al. postulated that the pathology of Parkinson's disease may involve a copper-catalyzed oxidative mechanism (17). Hirsh et al. reported an increase in the presence of dopaminergic melanin in the substantia nigra of Parkinson patients (22). Quinones are the precursors to melanin formation and can arise from direct oxidation of a dihydroquinone by $\mathrm{Cu}$ (II) or by an autoxidation mechanism initiated, and subsequently propagated, by either superoxide or semiquinone $(23,24)$.

The data reported here demonstrate for the first time that the copper-loaded form of S100B functions as a catecholase, catalyzing the two-electron oxidation of catechols. The 
evidence provided indicates that the catecholase chemistry is copper initiated. Comparison to the reactivities of tyrosinase and $\mathrm{Cu}(\mathrm{II})$-containing metallothioinein III (MT3), ${ }^{1}$ also referred to as growth inhibitory factor (25), allows for mechanistic insight into the catecholase activity associated with $\mathrm{Cu}-\mathrm{S} 100 \mathrm{~B}$.

\section{MATERIALS AND METHODS}

Protein Purification. The purification method employed for isolating $\mathrm{S} 100 \mathrm{~B}$ was an adaptation of that reported (1, 16,26 ). All procedures were carried out at $4{ }^{\circ} \mathrm{C}$ in $10 \mathrm{mM}$ acetate buffer ( $\mathrm{pH}$ 6.0), unless otherwise indicated. Bovine brains were peeled, washed, and homogenized. Following centrifugation ( $1 \mathrm{~h}, 10000 \mathrm{~g}$ ), DEAE-32 resin (Whatman) was added to the supernatant. The resin was loaded into a column and washed sequentially with 50 and $100 \mathrm{mM}$ acetate buffer (pH 6.0). Protein was eluted with $0.5 \mathrm{M}$ buffer. The yellow, protein-containing fractions were loaded onto a Sephadex A25 (Pharmacia) column and washed with $0.2 \mathrm{M}$ acetate. Protein was eluted with $0.4 \mathrm{M} \mathrm{NaCl}$ in $0.2 \mathrm{M}$ acetate buffer. The first protein-containing peak from this elution was pooled and concentrated using an Amicon concentrator equipped with a YM-3 membrane prior to being loaded onto a Sephacryl 100HR (Pharmacia) gel filtration column. Elution with $0.15 \mathrm{M}$ acetate buffer resulted in four protein-containing peaks. Peaks 3 and 4 were collected and concentrated. The protein fractions were treated with trypsin and analyzed by matrix-assisted light desorption ionization time-of-flight mass spectroscopy (MALDI-TOF) (Sloan-Kettering Mass Spectroscopy Facility). Fragment and total protein masses confirm the identities of $\mathrm{S} 100 \beta$ and MT3 contained in peaks 3 and 4 , respectively. Protein concentrations were determined spectrophotometrically using the following extinction coefficients $\left[\epsilon_{280}=3400 \mathrm{M}^{-1} \mathrm{~cm}^{-1}\right.$ for S100B (27) and $\epsilon_{250}=$ $60000 \mathrm{M}^{-1} \mathrm{~cm}^{-1}$ for MT3 (28)]. Apoprotein was prepared by dialysis of native S100B against $2.0 \mathrm{mM}$ EDTA in 10 $\mathrm{mM}$ Tris buffer ( $\mathrm{pH}$ 7.2) or by addition of $2.0 \mathrm{mM}$ EDTA followed by elution of apoprotein on a Sephadex G-25 column. Copper(II) addition to apo-S100B was performed by overnight incubation with $\mathrm{Cu}\left(\mathrm{SO}_{4}\right)$ followed by multiple dilution/concentration cycles using an Amicon concentrator equipped with a YM-3 membrane or passing the Cu-protein solution down a Sephadex G-25 column. Tyrosinase, Mnsuperoxide dismutase, and catalase were purchase from Sigma and used without further purification. MT3 was oxidized by dialyzing the protein against ferricyanide.

Catecholase Assay. Steady-state kinetic data were collected using visible absorption spectroscopy to monitor product formation. All assays were conducted in $20 \mathrm{mM}$ Tris buffer, pH 7.2 at $20^{\circ} \mathrm{C}$. Concentrations of the oxidized forms of DOPA (DOPAchrome: $\epsilon_{475}=3600 \mathrm{M}^{-1} \mathrm{~cm}^{-1}$ ) (29), adrenaline (adrenachrome: $\epsilon_{550}=750 \mathrm{M}^{-1} \mathrm{~cm}^{-1}$ ), and noradrenaline (noradrenachrome: $\epsilon_{550}=2593 \mathrm{M}^{-1} \mathrm{~cm}^{-1}$ ) were determined spectrophotometrically. Extinction coefficients for adrenachrome and noradrenachrome were obtained by monitoring the total oxidation of a known amount

\footnotetext{
${ }^{1}$ Abbreviations: EPR, electron paramagnetic resonance; DOPA, dihydroxyphenylalanine; MT, metallothionein; SOD, superoxide dismutase; apo, metal free; MALDI-MS, matrix-assisted light desorption ionization mass spectroscopy; EDTA, ethylenediaminetetraacetic acid; Tris, tris(hydroxymethyl)aminomethane.
}

of catecholamine by large amounts of tyrosinase. Assay conditions included $10.4 \mu \mathrm{M} \mathrm{Cu}-\mathrm{S} 100 \mathrm{~B}, 25 \mu \mathrm{M}$ MT3, or $0.05 \mu \mathrm{M}$ tyrosinase. Initial rates were recorded for a variety of substrate concentrations. Solution dioxygen concentrations were quantified polarographically using a YSI Inc. oxygraph with a $1.5 \mathrm{~mL}$ water-jacketed cell equipped with a Clark electrode. The oxygraph was calibrated by addition of a known amount of an anaerobic solution of protocatechuate to an oxygen-saturated solution containing protocatechuate 3,4-dioxygenase (ca. $5 \mu \mathrm{M}$ ) (30). Mn-superoxide dismutase (800 units) and catalase (10000 units) were added to the oxygen consumption experiments to monitor superoxide and/ or peroxide release during the oxidation of catecholamines. $\mathrm{Mn}-\mathrm{SOD}$ is used because Fe-SOD displays residual catecholase activity.

Spectroscopic Methods. Absorption spectra were collected on a Hewlett-Packard 8452A diode array spectrometer and a Shimadzu UV2401-PC scanning spectrometer. Temperature was controlled with a circulating water bath. X-band EPR spectra were recorded on a Bruker ESP 300 spectrometer equipped with an Oxford ESR 910 cryostat for lowtemperature measurements. Spin quantitation was determined relative to a Cu-EDTA standard. The Oxford thermocouple temperature was calibrated using a carbon glass resistor temperature probe (CGR-1-1000, Lake Shore Cryotronics). The magnetic field modulation was $100 \mathrm{kHz}$ at an amplitude of $1.0 \mathrm{mT}$. All experimental data were collected under nonsaturating conditions. Copper and calcium concentrations were determined using a Perkin-Elmer 3100 flame atomic absorption spectrometer.

\section{RESULTS AND DISCUSSION}

Copper Binding Sites. S100B has been shown to bind 4 equiv of copper per protein dimer $(\beta \beta)$ (16). Absorption and EPR spectroscopy have been employed to gain further insight into the coordination environment of the copper bound to $\mathrm{S} 100 \mathrm{~B}$. The absorption spectrum of $\mathrm{Cu}-\mathrm{S} 100 \mathrm{~B}$ shows an absorption maximum at $650 \mathrm{~nm}\left(\epsilon=85 \mathrm{M}^{-1} \mathrm{~cm}^{-1}\right)$ (Figure 1) responsible for the faint blue color of the protein and is characteristic of $\mathrm{Cu}$ (II) bound in a square-based pyramid coordination geometry (31). The frozen solution EPR spectrum of $\mathrm{Cu}(\mathrm{II})-\mathrm{S} 100 \mathrm{~B}$ (Figure 1) is typical of a type II copper center with $g_{\perp}=2.06, g_{\|}=2.28$, and $A=184 \times$ $10^{-4} \mathrm{~cm}^{-1}(32,33)$. These values are consistent with either two or three $\mathrm{N}$-donors to $\mathrm{Cu}$ (II) (34). The concentration of EPR-detectable $\mathrm{Cu}$ (II), obtained by integration of the EPR signal, is roughly equal to the total amount of copper in the system, indicating that all of the copper resides in mononuclear $\mathrm{Cu}(\mathrm{II})$ sites. It is clear that no strong coupling between the copper ions bound to S100B is detected, such as that existing in the type III dinuclear copper centers of tyrosinase and catechol oxidase (35). The EPR signal is eliminated following anaerobic treatment with dithionite, ascorbate, or L-DOPA and reappears following exposure to dioxygen. Integration of the signal confirms that the concentration of $\mathrm{Cu}(\mathrm{II})$ has not changed. The EPR and visible spectra of $\mathrm{Cu}(\mathrm{II})-\mathrm{S} 100 \mathrm{~B}$ are not perturbed by the addition of $\mathrm{Ca}(\mathrm{II})$.

The NMR- and X-ray-derived structures of the Ca-loaded protein clearly demonstrate the carboxylate-rich binding sites for $\mathrm{Ca}$ (II) (13). No X-ray or NMR structures exist for the 


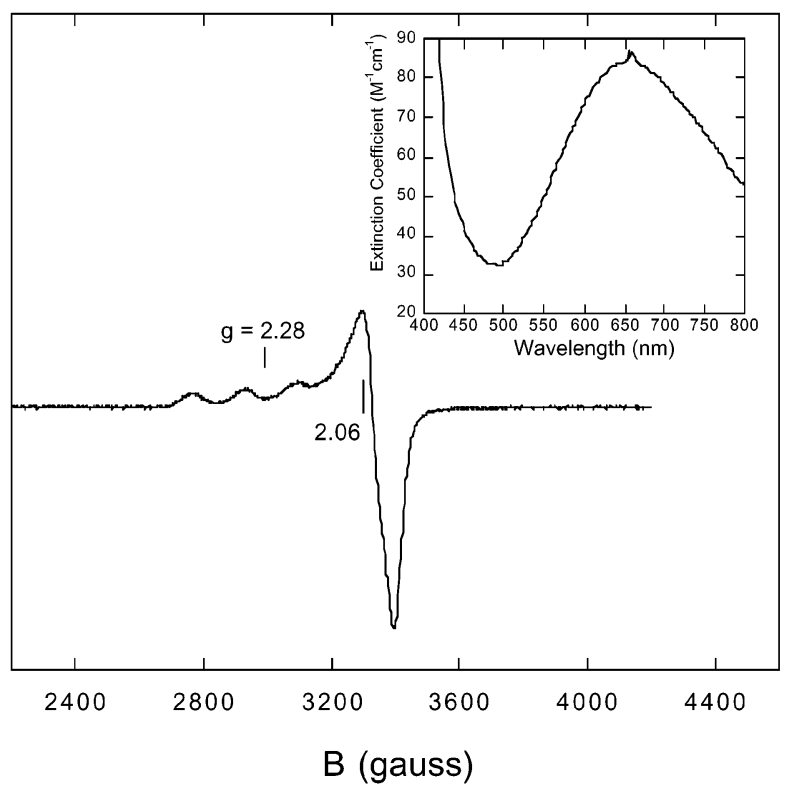

FIGURE 1: EPR spectrum of $\mathrm{Cu}-\mathrm{S} 100 \mathrm{~B}$ from bovine brain collected at $4 \mathrm{~K}$. Insert: Absorption spectrum of Cu-S100B. Protein is in 20 $\mathrm{mM}$ Tris buffer, $\mathrm{pH}$ 7.2.

copper-loaded form of any of the S100 proteins. Copper(II) binding does not hinder $\mathrm{Ca}(\mathrm{II})$ binding, as a full complement of four $\mathrm{Ca}(\mathrm{II})$ are able to bind to the $\mathrm{Cu}$-loaded protein. Similarly, $\mathrm{Ca}$ (II) bound to the protein does not interfere with $\mathrm{Cu}(\mathrm{II})$ binding. Copper and calcium do not appear to compete for endogenous ligands. It is clear from these studies that copper binds to two or three nitrogen-containing ligands. The $\mathrm{N}$-terminus of bovine S100B is acetylated and therefore unavailable for copper ligation (36). All structurally characterized type II copper proteins have at least two endogenous histidines bound to the copper center; therefore, it appears likely that two or three His residues are coordinated to the copper centers.

The primary sequence of bovine $\mathrm{S} 100 \beta$ has five His residues at positions $15,25,42,85$, and 90 . A potential binding site may include $\mathrm{His}_{15}$ and $\mathrm{His}_{25}$, which are shown in the crystal structure of the $\mathrm{Ca}(\mathrm{II})$-loaded $\beta$ peptide to be located $3.95 \AA$ apart $(12-14)$. No other His residues located on the same single $\beta$ strand lie closer than $19 \AA$ to another His. This suggests that the other copper binding sites likely reside at the $\beta \beta$ interface incorporating His residues from both strands. $\mathrm{His}_{15}$ is located $6.8 \AA$ from $\mathrm{His}_{90}$ on the adjacent chain (12).

The crystal structure of S100A7 with zinc and calcium bound is shown in Figure 2 (37). Significant homology exists in the primary structures of the S100A7 and S100B proteins. In particular, the ligands shown bound to the calcium and zinc sites in S100A7 are conserved in the S100B sequence. The zinc binding site in S100A7 is shown to lie at the $\beta \beta$ interface and is comprised of three His ligands, His ${ }_{86}$ and His $_{90}$ from one $\beta$ strand and $\mathrm{His}_{17}$ from the other. It is likely that the copper/zinc binding sites in S100B are similarly constructed. Cysteine residues are also highlighted in Figure 2 , illustrating that they are not located near the His-rich metal binding site. Bovine $\mathrm{S} 100 \beta$ has two thiolates located more than $19 \AA$ apart and $9 \AA$ from the closest His residue (14). It is unlikely that cysteine residues are coordinated to the copper in S100B.

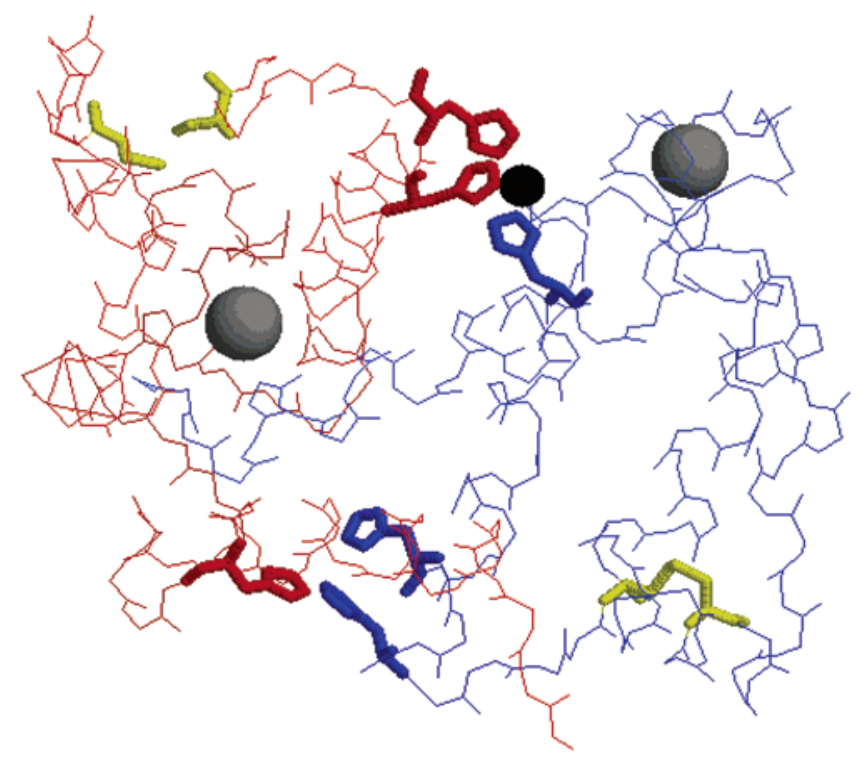

FIGURE 2: Three-dimensional structure of S100A7 (37). The two strands of the homodimer are shown in red and blue, $\mathrm{Zn}$ (II) is in black, $\mathrm{Ca}(\mathrm{II})$ is in gray, and Cys residues are in yellow. All Cys and His residues are shown to illustrate their positions relative to the bound metal ions.

It is important to note that the Ca-S100B protein used in the copper binding study has not been treated with EDTA. EDTA is only used to prepare the calcium-free form of the protein. The subsequent finding that $\mathrm{Ca}-\mathrm{S} 100 \mathrm{~B}$ is able to bind a full complement of copper confirms that EDTA does not play a role in the copper binding properties reported here. Further, the EPR parameters for Cu-EDTA ( $g=2.32$ and $A$ $\left.=157 \times 10^{-4} \mathrm{~cm}^{-1}\right)$ are sufficiently different from those reported for $\mathrm{Cu}-\mathrm{S} 100 \mathrm{~B}$ to conclude that the EPR-detectable copper in these samples is not Cu-EDTA.

Catecholase Activity Associated with $\mathrm{Cu}$-S100B. The cupric form of $\mathrm{Cu}-\mathrm{S} 100 \mathrm{~B}$ reacts readily with DOPA as determined by an increase in visible absorption arising from the DOPAchrome product. DOPAchrome is the product of a nonenzymatic polymerization of DOPAquinone. The red color associated with DOPAchrome was used to quantify product formation. Initial rates for this reaction increase in direct proportion to the concentration of $\mathrm{Cu}-\mathrm{S} 100 \mathrm{~B}$ (data not shown). The consumption of dioxygen during this reaction was monitored polarographically with a Clark electrode. Simultaneous oxygen consumption and visible absorption measurements enable us to establish the stoichiometry of catechol oxidation as 1:1 mol equiv of dioxygen consumed per quinone product produced. Neither the metal-free nor calcium forms of S100B react with DOPA. Upon completion of the reaction, a pinkish precipitate forms. Protein quantitation confirms that no protein is lost during this reaction. The pinkish precipitate is likely a dopaminergic melanin formed via the polymerization of the quinone product resulting from DOPA oxidation.

Characterization of the $\mathrm{Cu}-\mathrm{S} 100 \mathrm{~B}$ oxidation of L-DOPA under steady-state conditions demonstrates MichaelisMenten behavior. Kinetic constants are reported in Table 1. For comparative purposes, we also report kinetic data for catechol oxidation by tyrosinase, a dinuclear copper enzyme which serves a native catecholase function in the production of melanin, which are comparable to those previously reported for this enzyme $(38,39)$. The reactivity of $\mathrm{Cu}-\mathrm{S} 100 \mathrm{~B}$ 
Table 1: Steady-State Kinetic Constants for Tyrosinase and Cu-S100B with Catecholamine Substrates

\begin{tabular}{|c|c|c|c|c|c|c|}
\hline \multirow[b]{2}{*}{ substrate } & \multicolumn{3}{|c|}{ tyrosinase } & \multicolumn{3}{|c|}{$\mathrm{Cu}-\mathrm{S} 100 \mathrm{~B}$} \\
\hline & $K_{\mathrm{m}}(\mathrm{M})$ & $k_{\text {cat }}\left(\mathrm{s}^{-1}\right)$ & $k_{\mathrm{cat}} / K_{\mathrm{m}}\left(\mathrm{M}^{-1} \mathrm{~s}^{-1}\right)$ & $K_{\mathrm{m}}(\mathrm{M})$ & $k_{\text {cat }}\left(\mathrm{s}^{-1}\right)$ & $k_{\mathrm{cat}} / K_{\mathrm{m}}\left(\mathrm{M}^{-1} \mathrm{~s}^{-1}\right)$ \\
\hline L-DOPA & $4.55 \times 10^{-4}$ & 19.3 & $4.24 \times 10^{4}$ & $2.23 \times 10^{-4}$ & $4.59 \times 10^{-4}$ & 2.06 \\
\hline D-DOPA & $1.16 \times 10^{-3}$ & 30.4 & $2.62 \times 10^{4}$ & $2.19 \times 10^{-4}$ & $3.38 \times 10^{-4}$ & 1.54 \\
\hline L-adrenaline & $2.64 \times 10^{-4}$ & $2.99 \times 10^{-2}$ & $1.13 \times 10^{2}$ & $2.39 \times 10^{-5}$ & $1.48 \times 10^{-6}$ & $6.19 \times 10^{-2}$ \\
\hline L-noradrenaline & $1.01 \times 10^{-4}$ & $1.87 \times 10^{-3}$ & $1.83 \times 10^{1}$ & $1.94 \times 10^{-5}$ & $9.12 \times 10^{-8}$ & $4.70 \times 10^{-3}$ \\
\hline
\end{tabular}

with other catechol substrates was examined to determine if this small protein is capable of substrate specificity. The $K_{\mathrm{m}}$ and $k_{\text {cat }}$ values derived from steady-state kinetic measurements are indistinguishable for L- and D-DOPA, suggesting that $\mathrm{Cu}-\mathrm{S} 100 \mathrm{~B}$ does not exert stereochemical selectivity. Similar kinetic data for tyrosinase oxidation of $\mathrm{L}^{-}$and D-DOPA demonstrate more than a 2-fold increase in $K_{\mathrm{m}}$ for the D- over the L- stereoisomer (Table 1), establishing the ability of this enzyme to discriminate between the optical isomers (38).

Kinetic constants are also reported for the reactions of $\mathrm{Cu}-$ S100B and tyrosinase with adrenaline and noradrenaline (Table 1). These data provide further evidence that the copper centers in S100B are accessible to and will react with a variety of catechol substrates. For tyrosinase, $K_{\mathrm{m}}$ and $k_{\text {cat }}$ have been shown to decrease as much as 2 and 3 orders of magnitude, respectively, as the electron-withdrawing character of the para substituent on the catechol ring is increased (40). Greater electron-withdrawing capacity in the para position results in greater binding affinity and lower turnover rates. Similar trends are seen for the rates of catechol oxidation by $\mathrm{Cu}(\mathrm{II})$ complexes which have been reported to correlate with Hammett $\sigma_{\mathrm{p}}$ values (40). The hydroxylated benzylic carbon of adrenaline and noradrenaline is more electron withdrawing than the corresponding methylene at the same position in DOPA. Like tyrosinase, S100B is not as efficient in the turnover of these catecholamines.

The rate constants reported here clearly demonstrate that the mononuclear copper sites in $\mathrm{Cu}-\mathrm{S} 100 \mathrm{~B}$ are much less efficient than the dinuclear sites in tyrosinase. Similar trends have been observed for dinuclear and mononuclear copper complexes and their reactivity toward catechol oxidation (41, 42). Dinuclear copper complexes routinely show significantly higher catechol oxidation rates. The close proximity of the two copper atoms is one of the factors influencing these enhanced rates. Depending upon geometric and steric constraints imposed by the ligand, mononuclear complexes display drastically decreased rates or no reactivity $(40,41)$. Nonplanar mononuclear $\mathrm{Cu}$ (II) complexes display activity rates toward 3,5-di-tert-butylcatechol of $(0.5-1) \times 10^{-3}$ $\mu \mathrm{mol}$ of substrate $\left(\mathrm{mg}\right.$ of catalyst) ${ }^{-1} \min ^{-1}(41,43,44,45)$, comparable to the rates observed here for the reaction of DOPA with $\mathrm{Cu}-\mathrm{S} 100 \mathrm{~B}$ [0.11 $\mu \mathrm{mol}$ of substrate (mg of copper $)^{-1} \mathrm{~min}^{-1}$. Planar mononuclear $\mathrm{Cu}$ (II) complexes are generally unreactive toward catechols. Steric match between the catechol substrate and the $\mathrm{Cu}$ (II) complex appears to be the primary factor determining catechol oxidation rates (41).

The $\mathrm{Cu}(\mathrm{II})-\mathrm{S} 100 \mathrm{~B}$ EPR signal is eliminated following anaerobic treatment of the protein with DOPA, demonstrating the direct involvement of the copper center in the initial oxidation of the catecholamine. However, formation of a quinone from a catechol is a two-electron oxidation. We see no EPR evidence of a semiquinone formed during this
Scheme 1: Mechanism of Copper-Initiated Catechol Autoxidation

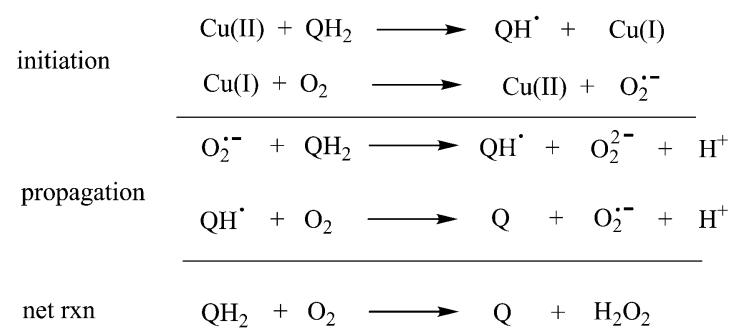

reaction. The $\mathrm{Cu}(\mathrm{II})$ EPR signal is fully restored upon exposure to dioxygen, demonstrating that these copper centers are able to activate dioxygen. Superoxide, however, is also capable of initiating and propagating the autoxidation of catechols as outlined in Scheme 1.

Superoxide dismutase (SOD) and catalase catalyze the following disproportionation reactions, respectively:

$$
\begin{gathered}
2 \mathrm{O}_{2}^{-}+2 \mathrm{H}^{+} \rightarrow \mathrm{O}_{2}+\mathrm{H}_{2} \mathrm{O}_{2} \\
2 \mathrm{H}_{2} \mathrm{O}_{2} \rightarrow \mathrm{O}_{2}+2 \mathrm{H}_{2} \mathrm{O}
\end{gathered}
$$

SOD and catalase were added to the assay mixtures independently to probe for superoxide and/or peroxide production, respectively. Addition of SOD had no effect on the amount of dioxygen consumed during the reaction of $\mathrm{Cu}-\mathrm{S} 100 \mathrm{~B}$ and DOPA, indicating that superoxide is not generated during this reaction cycle. SOD also had no effect on the amount of dioxygen consumed by tyrosinase during turnover. This is not surprising, given the efficiency of the dinuclear copper centers at facilitating the two-electron reduction of dioxygen during regeneration of the active cluster.

The SOD control is essential for differentiating a true catecholase activity from an autoxidative mechanism. For comparison, we have characterized the kinetics of L-DOPA oxidation by $\mathrm{Cu}-\mathrm{MT} 3$ and found that it also demonstrates Michaelis-Menten behavior (data not shown). Addition of SOD inhibits the Cu-MT3 reaction with DOPA by $77 \%$, suggesting that catechol oxidation is superoxide dependent and likely proceeds through an autoxidative mechanism. Superoxide deactivation of catecholamines is well documented and has recently been linked to the nonresponse of sympathetic vasoconstrictors associated with septic shock (46). Moreover, both mechanisms point to the direct involvement of copper in the oxidative generation of dopaminergic melanin.

Addition of catalase to the $\mathrm{Cu}-\mathrm{S} 100 \mathrm{~B}$ reaction with L-DOPA results in a 50\% decrease in the amount of dioxygen consumed. This result suggests that hydrogen peroxide is released at some point during the catalytic cycle. Catalase has no effect on similar measurements made with tyrosinase, 
Scheme 2: Mechanism of Copper-Catalyzed Catechol Oxidation $^{a}$

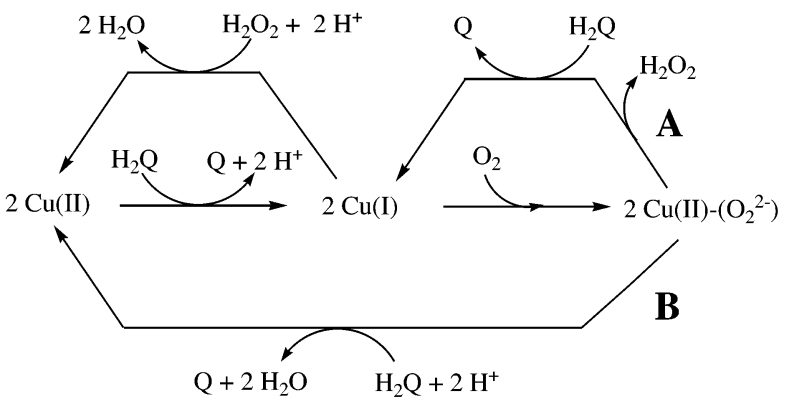

${ }^{a}$ Pathway A is the proposed mechanism for Cu-S100B. Pathway B is that utilized by type III dinuclear copper enzymes.

confirming that peroxide is not released from the type III dinuclear center during its reaction with L-DOPA.

The results presented here allow us to propose a catalytic cycle for $\mathrm{Cu}-\mathrm{S} 100 \mathrm{~B}$ (Scheme 2). The 1:1 ratio of oxygen consumed to quinone produced is consistent with the release of hydrogen peroxide and is mechanistically distinct from the type III dinuclear enzymes, tyrosinase and catechol oxidase, which exhibit a 1:2 ratio and do not release hydrogen peroxide (47-49). Combined with the lack of superoxide release, it appears that two independent type II copper centers work simultaneously to effect the two-electron oxidation of catecholamine substrates. It should be reiterated that no evidence exists to suggest that these sites are coupled, although they may be in close proximity. The lack of semiquinone observed in the anaerobic treatment of $\mathrm{Cu}$ S100B and catecholamines also suggests that two copper centers are close enough to effect oxidation of substrate before product is released.

\section{CONCLUSION}

We report here evidence of catechol oxidation by $\mathrm{Cu}$ S100B, the first reported catalytic activity associated with this protein. It is clear from these data that the copper centers in the protein are directly involved in the catechol oxidation. The extremely low levels of activity suggest that this protein likely plays no direct metabolic role in the biodegradation of catecholamines. However, the insensitivity of the $\mathrm{Cu}$ S100B reaction to SOD, an antioxidative mechanism employed by the cell, may implicate this type of oxidative mechanism in the slow progression of neurodegenerative diseases (17).

\section{ACKNOWLEDGMENT}

Mathew Posewitz (Sloan Kettering) is thanked for collecting MALDI-MS data.

\section{REFERENCES}

1. Isobe, T., Nakajima, T., and Okuyama, T. (1977) Biochim. Biophys. Acta 494, 222-232.

2. Fan, K. (1982) Brain Res. 237, 498-503.

3. Isobe, T., and Okuyama, T. (1978) Eur. J. Biochem. 89, 379388.

4. Cocchia, D., Michetti, F., and Donato, R. (1981) Nature 294, 8587.

5. Baudier, J., Briving, C., Deinum, J., Haglid, K., Sirskog, L., and Wallin, M. (1982) FEBS Lett. 147, 165-168.

6. Endo, T., and Hidaka, H. (1983) FEBS Lett. 161, 235-238.
7. Zimmer, D. B., and VanEldik, L. J. (1986) J. Biol. Chem. 261, 11424-11428.

8. Baudier, J., Delphin, C., Grunwald, D., Khochbin, S., and Lawrence, J. J. (1992) Proc. Natl. Acad. Sci. U.S.A. 89, 1162711631.

9. Pozdnyakov, N., Goraczviak, R., Margulis, A., Duda, T. Sharma, R. K., Yoshida, A., and Sitaramayya, A. (1997) Biochemistry 36, 14159-14166.

10. Baudier, J., Glasser, N., and Gerard, D. J. (1986) J. Biol. Chem. $261,8192-8203$.

11. Heizmann, C. W., and Cox, J. A. (1998) BioMetals 11, 383397.

12. Kilby, P. M., Van Eldik, L. J., and Roberts, G. C. (1996) Structure 4, 1041-1052.

13. Matsumura, H., Shiba, T., Inoue, T., Harada, S., and Yasushi, K. A. I. (1998) Structure 6, 233-241.

14. St. Charles, R., and Kumar, V. D. (1994) J. Mol. Biol. 236, 953957.

15. Baudier, J., and Cole, D. R. (1989) Biochem. J. 264, 79-85.

16. Nishikawa, T., Matsui-Lee, I. S., Shiraishi, N., Ishikawa, T., Ohta, Y., and Nishikimi, M. (1997) J. Biol. Chem. 272, 23037-23041.

17. Pall, H. S., Williams, A. C., Blake, D. R., Lunec, J., Gutteridge, J. M., and Hall, M. (1987) Lancet 1, 238-241.

18. Multhaup, G., Schlicksupp, A., Hesse, L., Beher, D., Ruppert, T., Masters, C. L., and Beyreuther, K. (1996) Science 271, 14061409.

19. Wiedau-Pazo, M., Got, J. J., Rabizadeh, S., Gralla, E. B., Roe, J. A., Lee, M. K., Valentine, J. S., and Bredesen, D. E. (1996) Science 271, 515-518.

20. Brown, D. R., Qin, K., and Herms, J. W. (1997) Nature 390, 684687.

21. Rae, T. D., Schmidt, P. J., Pufahl, R. A., Culotta, V. C., and O'Halloran, T. V. (1999) Science 284, 805-808.

22. Hirsh, E. C. (1992) Ann. Neurol. 32, S88.

23. Misra, H. P., and Fridovich, I. (1972) J. Biol. Chem. 247, 31703175.

24. Ingold, K. U., Bowry, V. W., Stocker, R., and Walling, C. (1993) Proc. Natl. Acad. Sci. U.S.A. 90, 45-49.

25. Uchida, Y., Takio, K., Titani, K., Ihara, Y., and Tomonaga, M. (1991) Neuron 7, 337-347.

26. Gasparov, V. S., Nalbandyan, R. M., and Buniatian, H. C. (1979) FEBS Lett. 97, 37-39.

27. Baudier, J., and Gerard, D. (1986) J. Biol. Chem. 261, 82048212.

28. Pountney, D. L., Fundel, S. M., Faller, P., Birchler, N. E., Hunziker, P., and Vasák, M. (1994) FEBS Lett. 345, 193-197.

29. Mason, H. S. (1949) J. Biol. Chem. 172, 83-99.

30. Wolgel, S. A., Dege, J. E., Perkins-Olson, P. E., Jaurez-Garcia, C. H., Crawford, R. L., Munch, E., and Lipscomb, J. D. (1993) J. Bacteriol. 175, 4414-4426.

31. Hathaway, B. J., and Billing, D. E. (1970) Coord. Chem. Rev. 5 , 143-207.

32. Basosi, R., Antholine, W. E., and Hyde, J. S. (1993) in Biological Magnetic Resonance (Berliner, L. J., and Ruben, J., Eds.) Vol. 13, p 103, Plenum Press, New York.

33. Solomon, E. I., Penfield, K. W., and Wilcox, D. E. (1983) Struct. Bonding 53, 1-57.

34. Peisach, J., and Blumberg, W. E. (1974) Arch. Biochem. Biophys. 165, 691-708.

35. Solomon, E. I., Tuczek, F., Root, D. E., and Brown, C. A. (1994) Chem. Rev. 94, 827-856.

36. Harford, C., and Sarkar, B. (1997) Acc. Chem. Res. 30, $123-$ 130 .

37. Brodersen, D. E., Nyborg, J., and Kjeldgaard, M. (1999) Biochemistry 38, 1695-1704.

38. Espín, J. C., García-Ruiz, P. A., Tudela, J., and García-Cánovas, F. (1998) Biochem. J. 331, 547-551.

39. Duckworth, H. W., and Coleman, J. E. (1970) J. Biol. Chem. 245, 1613-1623.

40. Belle, C., Beguin, C., Gautier-Luneau, I., Hamman, S., Philouze, C., Pierre, J. L., Thomas, F., Torelli, S., Saint-Aman, E., and Bonin, M. (2002) Inorg. Chem. 41, 479-491.

41. Oishi, N., Nishida, Y., Ida, K., and Kida, S. (1980) Bull. Chem. Soc. Jpn. 53, 2847-2850.

42. Malachowski, M. R., Huynh, H. B., Tomlinson, L. J., Kelly, R. S., and Furbee, J. W., Jr. (1995) J. Chem. Soc., Dalton Trans., $31-36$.

43. Malachowski, M. R., Davidson, M. G., and Hoffman, J. N. (1989) Inorg. Chim. Acta 157, 91-94. 
44. Malachowski, M. R., and Davidson, M. G. (1989) Inorg. Chim. Acta 162, 199-204.

45. Malachowski, M. R., Tomlinson, L. J., Davidson, M. G., and Hall, M. J. (1992) J. Coord. Chem. 25, 171-174.

46. Macarthur, H., Westfall, T. C., Riley, D. P., Misko, T. P., and Salvemini, D. (2000) Proc. Natl. Acad. Sci. U.S.A. 97, 97539758.
47. Karlin, K. D. (1993) Science 261, 701-708.

48. Solomon, E. I., Sundaram, U. M., and Machonkin, T. E. (1996) Chem. Rev. 96, 2563-2605.

49. Eicken, C., Krebs, B., and Sacchettini, J. C. (1999) Curr. Opin. Struct. Biol. 9, 677-683.

BI0205799 